\title{
A Critical Review on the Rise of Social Enterprise as a Foundation of Motivation and Innovation in Entrepreneurship
}

\author{
Tan Seng Teck ${ }^{1}$, Nanthakumar Karuppiah ${ }^{2}$, Wong Chee Hoo ${ }^{1}$ \\ ${ }^{1}$ Senior Lecturer, Faculty of Business, Communication and Law (FOBCAL), INTI International University, \\ Malaysia \\ ${ }^{2}$ Senior Lecturer, University of Hertfordshire Centre, INTI International College, Malaysia \\ Correspondence: Tan Seng Teck, Senior Lecturer, Faculty of Business, Communication and Law (FOBCAL), \\ INTI International University, Malaysia.
}

Received: November 11, 2019

doi:10.5539/ibr.v13n1p259
Accepted: December 11, 2019

Online Published: December 27, 2019

URL: https://doi.org/10.5539/ibr.v13n1p259

\begin{abstract}
This paper examines the emergence of social enterprise in modern business world and argues that conventional entrepreneurship in open market system, capitalism and laissez faire is retreating and giving way to more socially anchored entrepreneurship. This paper addresses the question on the dynamic impacts of social enterprise on the trajectory of motivation, innovation and sustainability entrepreneurship in modern business world. This paper maintains that social enterprise is a growing and unstopable phenomenon and could assume the central role of entrepreneurship in future.
\end{abstract}

Keywords: social enterprise, motivation, innovation, entrepreneurship

\section{Conventional Entrepreneurship and Beyond}

An entrepreneur is define as "person who starts or organises a commercial enterprise especially one that involved a financial risk" (Barber, 1998). Entreprenuership is not an alien concept and there is little doubt that entrepreneurship plays integral economic role especially in a capitalist society. Adam Smith's laissez faire and inivisible hand notion provides an unconstrained market system to maximise an entrepreneur's pursuit of self interests (Shaw et al., 2015). Of course, conventional entrepreneurship bears two distinct hallmarks. One that serves entirely egoistic self interests (see Albert Carr, 1968) and one that has a utilitarian root i.e. where entrepreneurship is tied to promoting the aggregated pleasure and common good of the society. No matter what the distinctions are, conventional entrepreneurship share four kindred features.

Firstly, entrepeurship engineers innovation and economic development creating what Schumpeter (1934) termed as 'creative destruction'. Such creative but cut throat competition is clearly seen in remarkably competitive industry like the Telco (see for example the demise of Nokia Inc.). Secondly, conventional entrpreneurship pays premium attention to the equation of supply and demand (see Rosa, 2012). Thirdly, new knowledge are developed with a forefront purpose of innovating products and services and with the prime intention of improving their efficacy mileage (Shane \& Venkataraman, 2000). Lastly, there is utmost emphasis on the right to own property (not so much of tangible property in terms of John Locke's perspectives) but in terms of intellectual property and inherent legal rights to defend it against infringement and any sorts of misuse.

Conventional entrepreneurship is a term synonymous to an entrepreneurial momentum primarily driven by market enterprise and external opportunities. By this, conventional entrepreneurship places utmost emphasis on the role of entrepreneurs in risks taking and harnessing external opportunities to maximise financial returns. In conventional entrepreneurship, the role of entrpreneurs is exclusive, whereas the interests of stakeholders remain a peripheral concern. This paper argues that this conventional form of entrepreneurship is no longer sustainable and is glaringly retreating in a modern society. There is enough evidence on a brewing vibrancy of social entrepreneurship which emphasises the role of entrepreneurs as a social construct. The role and welfare of society conversely become a primary contention in this new form of entreprenurship.

This paper is structured as follows. Firstly, the paper begins by exploring some key literatures of conventional entrepreneurship. Secondly, the paper eludicates some propelling factors that are retreating conventional entrepreneurship and how it changed the motivation, innovation and sustainability of entrepreneurship in modern 
economy. Finally but interestingly, to explore what the repercussions would be if an entrepreneur strays from its CSR accountability. The paper will explore these details in sequence below.

\section{Entrepreneurship and Social Enterpreneruship - A Literature Review}

Entrepreneurship is a well established term at least in its economic vibrancy as well as in academic research. Literatures and researches on entrepreneurship is quite plentiful. One popular way of looking at entrepreneurship is through the inside out approach. These literatures hold that entrepreneurship is predetermined by an individual's disposition and characteristics of the entrepreneur itself. Literatures on this inside out approach reflect the significant role and personality of entrepreneurs in risks taking which of course differ according to individuals (Scott et al., 2012). A host of other literatures explore the internal motivations of entrepreneurship. Locke (2000) for example advocates that the urge to be independent and free from control of others are the main proponents of entrepreneruship. This research is aligned with another study where the desire to attain financial freedom was a primary impetus for a rising trend of female entrepreneurs in Croatia (Hisrich, 1985).

Earlier researches on entrepreneurship however, are focused on individual traits, personality and characteristics (see Copper \& Dunkelberg, 1987, Lachman, 1980). Researches in this early era includes studying specific entrepreneurial characterics and one trait that was frequently studied is risk taking (Kilby, 1971). Palmer (1972) also proliferated that risks assessment and the willingness to undertake risks appear to be the primary motivation for entrepreneruship. This research is affirmed elsewhere (Sexton \& Bowman, 1986) that there is higher propensity for entrepreneurs to take risks as compared to the general population. However, researchers shared diverse opinion on the role of risks taking in entrepreneurship. Brokhaus (1980) for example asserted that there are no important differences between risks taking behaviours between entrepreneurs and those who are not.

Other researchers and 'gurus' in entrepreneurship argued that innovation is what sets entrepreneurs apart from the general public. Schumpeter's theory of entreprenuerial innovation brewed a major debate that entrepreneurs' endeavour for innovation was the key propulsion for the rise of entrepreneruship. Innovation has been classified as the functional characteristic of entrepreneurship (McClelland, 1961; Hornaday \& Aboud, 1971; Timmons, 1978). By this, innovation plays a condition precedent for sustainable entrepreneurship as well empowering the ability of entrepreneurs to generate constant wealth (Drucker, 1985). This argument was further perpetuated by Carland, Hoy, Boulton and Carland (1984) where they argued that innovation is a key factor that distinguished between a business person and an entrpreneur. Whilst many exemplified the role of innovation in entrepreneurship, others argued that innovation alone cannot explain the true essence of entrepreneurship (Hornaday,1992).

Perhaps one of the most studied characteristics of entrepreneurs is the need for achievement. Studies have postulated positive correlation between the need of achievement and the success of an entrepreneur (Hornaday \& Bunker, 1970; DeCarlo \& Lyons 1979). However, other studies (Borland, 1974; Hull et al., 1980) showed that the need for achievement must be matched by other conducive business environment.

The most common approach in understanding entrepreneurship involves an outside in approach in evaluating the opportunities and propositions in the market system. Kaufmann and Dant (2008) argue that entrepreneurship is flanked by external opportunities that are presented in the open system whilst Venkataraman (1997) perceives that entrepreneurs are keen opportunists that thrive on evolving business conditions (see also McClelland et al., 1958). All these literatures present an overwhelming point that entrepreneurs are heavily molded by external influences and the market circumstances presented (See aslo Timmons, 1994).

Of course, many other writings supported this argument. For example, Frese and De Kruif (2010) argue that deploring economic conditions in developing and undeveloped countries spike the increase in entrepreneurship activities. The need to live and survive are the main impetus for enterpreneurship, challenging private individuals and firms alike to attempt new markets, products or a combination of both. Tellegen (2011) takes this further and found that population growth and changes in economy have forwarded opportunities and fuelled the advents of entrepreneurship. For example, in this study, Tellegen argued that the rise of population led to increased demands and unmet needs. But of course, there are other factors that could have fuelled increasing entrepreneurship. For instance, dwindling economic conditions could cascade a rise in entrepreneurship activities, but this is different from the case of increased population. In meeting the declining economic conditions, the rise of entrpreneurship is matched by cut throat competition, price war and sends entrepreneurs into a spiral downturn. This study correctly categorised the external exigencies of entrepreneurship as one of a "necessity" and "opportunity". Whilst the later provides a bright outlook of opportunity for handsome profit, entrepreneurship by necessity presents a cut thorat and red ocean competition amongst the already crowded rivalries (Peter et al., 2012).

But even these lietratures are losing appeal. Individualistic entrepreneurial features are no longer a prime area of 
research. It lacks consistent and measurable outcome since everyone bears a distinctive appeal and culture. Measurement and consistent research is problematic and little consistencies appeared throughout the literatures that transpire (John, 2011). Instead, there are exalting volumes of writings on the rise of ethics as the underlying foundation of entrepreneurship. A newer breed of entrepreneurs, one where the goodwill and intention of entrepreneurship is steered by ethical consideration. Many termed this as social entreprenurship (Ana \& Mclean, 2015, see also Dees, 1998). Indeed, the study of social entrepreneurship has taken primary place in premier business schools and many textbooks wrote on this. Social entrepreneurship is a emerging breed of entrepreneurs that drive entrepreneurship and business to benefit within the community it operates. A business model that required entrepreneurs to rethink the human values and interests of the stakeholders.

For Mort et al (2003), social entrepreneurship perceives entrepreneurship as a "multidimensional construct" fabricated by intersections of multiple demands of relevant stakeholders. What this means is exactly that social entrpreneurship pays premium attention not only to the external exigencies and opportunities but to also balance the need to fulfil the human values and stakeholders' demands while maintaining business goals and visions. There are numerous examples that exmplify the rise of social entrepreneurship. Consider for example, the case of Gramen Bank in Bangladesh. The Bank was founded by Muhamad Yunus, an economic professor who saw the discrimination of conventional banking systems against the poorer community especially those in the agricultural industry. Yunus saw unrevealed potentials among the poorer community which most conventional banks would properly classify them as high risks group. Yunus established the bank with the sole purpose of furnishing financial assistance to lower rung populations that fell below certain treshold in income. In return, the borrowers were accountable to how they spent the money and were required to attend short courses to improve their understanding on how the money could have been better spent. The bank structure has since then inspired more establishments of this sort globally and currently reaching 17 million borrowers globally (Ana \& Mclean, 2015).

The impacts of social entrepreneurship is far reaching. It changes the trajectory of entrepreneurship from being self-centred to one that is deconstructed to fulfil social elements. It refocuses business where greater attention must be paid to fulfil corporate citizenship and the social charter. Social enterprise has taken the form and largely encroached into adjacent literatures and writings on CSR. The decision making powers and the creativity of entrepreneurs are now bechmarked against the need to fulfil the social citizenship. Entrpreneurs must maintain a socially favourable business environment and an entrepreneur's decision making powers are now diluted and benchmarked against the requirement to fulfil social needs (Rakesh et al., 2013). Entrepreneurs are obliged to implement socially desirable business policies one that underscored a firm's corporate citizenship and one that included a broad spectrum of obligations a firm owed to the society including fulfilling altruistic philanthropic obligations. These uprising pressure on social entrepreneurship is perhaps brought about by high profile incidences such as the Bhopal disaster and the Deep Water Horizon accident. The next section of this paper will explore how social entreprise and CSR has changed the trajectory of motivation, innovation and sustaining entrepreneurship in modern business.

\section{Social Enterprise, Changing the Trajectory of Entrepreneurship Motivation}

There lies a very interesting question. How has social entrepreneurship (if at all) changed the overall trajectory of entrepreneurship? For the purpose of this paper, it is argued that social entrepreneurship deeply alters entrepreneurship at three levels that is (1) the motivation of entrepreneurship, (2) the innovativeness of entrepreneurship and (3) the sustainability of entrepreneurship. This is summarised in Diagram 1 below:

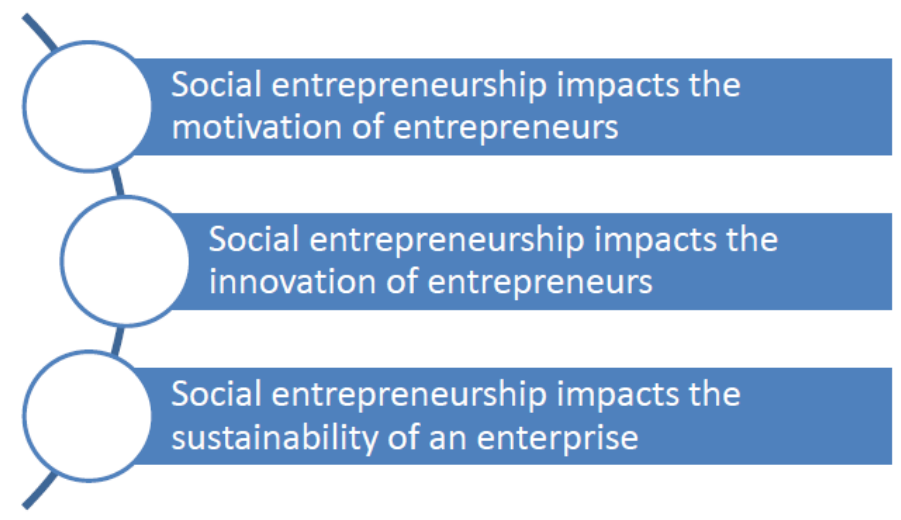




\section{Social Entrepreneurship and Motivation of Entrepreneurs}

The motivation of an entrepreneur is of course often intangible. It relates to a 'state of mind', dominated by individual characteristics like creativity, the need for achievement and even greed. Motivation for entrepreneurship provides the 'soul' of a corporation fueled either by external push factors or intrinsic pull factors of an individual entrepreneur. However, entrepreneurial motivation is not always abstract and in many cases clearly codified. For instance, the annual report (especially the forward by the Chief Executive Officer) and the slogan of a company often poject a non-conscious discourse of the firm's entrepreneurial motivations. For example, Honda's iconic slogan, "The Power of Dreams" drive the firms' innovative automotive designs since 1948. Steve Job's famous phrase "Stay Hungry Stay Foolish" remarks Apple's sensational quest for product and market superiority.

It is common that entrepreneurial motivations are fueled by commercial reasonings which underpin the value of a company. Most businesses are profit driven and their aim is to sustain competitive advantage within the market. So it begs the question how if at all the concept of social enterprise if at all change the trajectory of commercial intentions and motivations of entrepreneurs?

Indeed, social entrepreneurship plays an integral role in shaping and at times reshaping entrepreneurial motivation. It lays a foundation in which corporations must and should stay within the moral ambits of business. Social enterprise diminishes the tendency of corporations to venture far beyond acceptable moral norms. Social enterprise in this sense sets a limiting boundary on the and safeguards the moral parameters of corporate venture.

Let's assume that the society demands entrepreneurs to be ethical and exhibit a minimum content of morality. Let's also assume that the entrepreneur has breached this minimum content by enterprising a new business idea that was detrimental to the society. A backlash will ensue. A backlash caused by social-legal discontent leading to a retaliation aimed at the immoral enterprise. This backlash may be forceful enough to change the trajectory of the primary motivation in the business firm, unrooting the underlying foundation of its enterpreneurial motivation.

Consider the case of Shell's mismanagement of the Brent Oil Spar storage buoy saga in the Atlantic to strengthen this point. The saga led to furious backlash from the public and caused massive drop in share prices and distorted Shell's brand image. Post the saga, Shell's Annual Report described some interesting sub-conscious reactions towards the socio backlash. The report wrote (reproduced verbatim here indented):

We believe that we acted honourably in both cases. But that is not enough. Clearly, the conviction that you are doing things right is not the same as getting them right. For us at least, this has been a very salutary lesson. We were ready to learn from experiences, however painful, because of a planned process of change begun in 1994. It represented the most thorough and far reaching review for over 30 years - our Transformation. Nothing was sacrosanct and fundamentals were questioned: the structure, the way business is done, the quality of leadership, relationships with people and our vision of the future (Shell Inc. Annual Report 1998). [Emphasis added]

Shell appeared deconstructed by the backlash that in turn triggered deeply rooted entrepreneurial mood. A change that revolutionised the deep structure of entrepreneurship within the organisation. The highlighted words and phrases in the above excerpt proved these salient points. For instance, Shell expressed deep remorse over the incident. The phrases "very salutary lesson" and "however painful" clearly connoted a punctuated outcome on Shell. Other phrases indicated that Shell experienced deeply rooted entrepreneurial changes. These phrases, "most thorough far reaching-our transformation" where "fundamentals were questioned, including the "structure", "way business is done", "quality of relationships" and even Shell's "vision for the future" vindicated those rooted entrepreneurial changes in Shell. Shell has since then pledged to make environmental protection a priori objective within the organisation, a momentum that pays respect to social entrepreneurship.

One can also wirness such repercussions again in the recent Volkswagen (VW) Diesel Dupe. VW suffered a staggering $€ 1.7$-billion-dollar losses due to recalls. Approximately 11 million owners are affected by the scandal. Also, VW case portrays a precise illustration on how SE may reset the entrepreneurial value of firm and henceforth transforming it henceforth. VW entrepreneurial corruption was met by legal and social repercussions including a USD 4 billion legal suit. VW's Annual Report 2016 clearly explores the changing trajectory of entreprenurial motivation in the firm post the scandal. For this reason again the excerpt of the VW 2016 Annual Report is provided verbatim here indented. These two excerpts interestingly portrayed a changed entrepreneurial motivation trajectory. 
We deeply regret the behavior that gave rise to the diesel crisis. Such misconduct runs contrary to all the values that Volkswagen stands for" (VW Annual Report 2016 pp. 27) ....... This makes it all the more essential for us to establish a solid framework of values, in the form of our renewed commitment to sustainable, responsible business practices (VW Annual Report 2016 pp. 8) [Emphasis added].

It is clear that VW suffered tremendous backlash from this incident. The excerpts above clearly showed a changed entrepreneurial motivation and trajectory. VW recognises the breach of social enterprise runs contrary to all social values and now that VW pledged a renewed commitment to a refreshing start, a clear change in the trajectory of entrepreneurial motivation from purely commercial foundation to one that instils a foundation of moral values.

\section{Social Entrepreneurship and Innovation of an Enterprise}

The second question is how do social entrepreneurship change alter the innovative enterprise? Entrepreneurs thrive on innovation and creativity. But the question is whether there is a limit on what entrepreneurs can innovate? How do social enterprise present a moral barometer in the innovative values of a company? Can entrepreneurs innovate as they want or are their creativity bound by some social values? It is argued that social entreprise require firms to innovate within the boundaries of some moral values and bound to benefit the social construct. It is fair to say that firms cannot engage in free hand innovation but must carefully design their innovation to fit the moral requirements of the society. What happens if an innovation breach the implied social value and morality? What repercussions could ensue?

There is no deficit literatures on this, and evidences are plentiful that innovation are now increasingly benchmarked against social values. Many have demanded precautionary measures against unethical innovation and creativity that set back human values. For example, the UNESCO's World Commission on the Ethics of Scientific Knowledge and Technology (COMEST) argues that actions must be taken against innovations that destroy or at least diminishes the sense of human values (COMEST, 2005, p.12). Supervision on entrepreneurial innovation is a controversial concern as it opens wide the encroachment of government and trespasses freedom and liberty a hallmark of capitalism and democracy (Thierer, 2004). However, the supervision of entreprenurial innovation is a necessary evil. Of course, innovation leads to improvement in society. But it also leads to introduction of hazardous products and services, both that can be detrimental to moral values of the society which is aimed for. Genetically modified and engineered products (GME) are excellent examples unethical entrepreneurship. Nevertheless, products that create moral devaluation is more disturbing.

For example, the advents of smartphones that delimited cognitive development amongst children is a precise example (Stilgoe, 2013). Telco is an interesting example calling for continuum of discovering new technologies and creating fresh demands instead of fulfiling existing ones (Gilbert, 1994). Telco's were truly engrossed in producing disruptive technologies with the main intention of capturing market share as well as knocking the opponents out. Ambitious entrepreneurs are in constant quest for such descruptive innovations that are able to revamp the industrial structure. Steve Jobs fits such entrepreneurial spirit and he constantly stressed that innovation ought to produce leaping bounds and one that explodes revolutionary changes in an industry (Goodell, 1994). This paper does not question the necessity of innovations but it challenges the fact that unsupervised "permissionless innovation" may be detrimental to a society (Walter \& David, 2015).

This paper stresses that there is increasing need to inject social expectations against such innovative momentums, one that closely monitor if such innovations fit the description of a social enterprise. The recent complexity in introducing Iphone 8 is a clear example of over zealous innovation. Many quarters have remarked that Iphone 8 was an unnecessary invention with less improvements over the previous model and as usual sold at a premium price. It was argued that the brief introduction of Iphone 8 coupled with the abrupt revelation of Iphone X was unethical and misleads the consumers into unnecessary purchase and expenditure (Spence, 2017). Thus social enterprise provides another form of safeguards and moral limitations on innovation. Social moral values provide an intrinsic limitation on the extent of innovation within a business firm. Innovations that mark beyond expected social norms will be resisted or rejected. Therefore business firms are not permitted to innovate as they wish but are unconsiusly bound by moral limitations exerted by stakeholders. This notion is summed up in Diagram 2 below: 


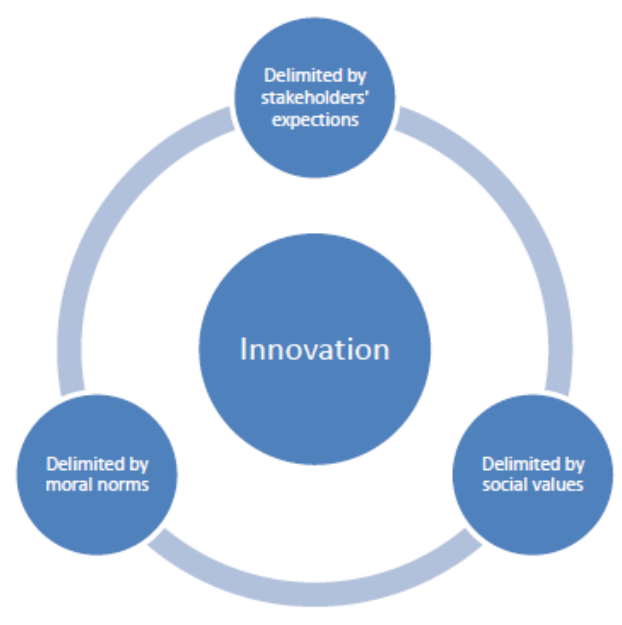

\section{Social Enterprise and Sustainability of Entrepreneurship}

The paper has so far explored the strong influence of social entrepreneurship on the motivation and innovation of entrepreneurship. This section of the paper now addresses the third and perhaps the most difficult question. How has social entrepreneurship change the way in which entrepreneurship is sustained? Logically, an entrepreneur defends its market by way of increasing competitive advantage by creating an edge over its competitors. A typical entrepreneur focuses and invests energy into adding values to products that are perceived valuable to the consumers. Also, a typical entrepreneur ensures that the business attains a compettive advantage over its competitors.

However, this paper argues that social entrepreneurship revamps how an entrepreneur defends and sustains its entrepreneurship. Social enterprise requires an enterpreneur to relook into how the business entity can integrate CSR within its business so that they could fulfil the social charter. Connecting social enterprise and CSR is very enlightening idea (Seelos \& Mair, 2004). Instead of looking at the compettive side of corporations, business firms should begin to smartly use social enterprise as a source of competitive advantage thus strengthening the sustainability of the firm.

Porter and Kramer's shared value model (2009) is a good illustration on how entrepreneurs could sustain their businesses through an integrated social entrepreneurship and CSR model. Porter argues that the shared value model revitalises entrepreneurship in that it draws closer alliance between the corperations and the society and that the choices an entrepreneur makes should generate reciprocal advantages. Porter maintains that entrepreneurs should defend their business activities through active integration of CSR within their business primary and secondary value chain. Businesses should not be defended solely on increasing market shares but considerable attention paid to developing outside in and inside out alliances within the value chain in the business framework.

Consider Starbucks ethical café practises. Starbucks takes pride in developing long time relationship with the coffee farmers in Cambodia, Vietnam and Venequela where these poor coffee farmers are constantly exploited for their produce. Starbuck's commitment to develop relationship includes providing financial aids to develop schools, hospitals and ensuring the welfare of the coffee farmers. They also ensures that the coffee is purchased at a rate that is higher than what the competitors offer. Starbucks commitment to their suppliers is an excellent example of social entrepreneurship and an integration of ethics in defending the firm's business position. As a result of this endeavour, Starbucks gained loyalty from the suppliers who ensure that Starbucks attain the best harvest of the beans as well as a constant and uninterrupted supply of products at a fairly constant price (Tan \& Gilbert, 2012, see also Rakesh et al., 2013).

Porter's integrated model not only benefits the firm it also generate benefits to the society in which it has place of business (Lantos, 2001). Porter's model provides a reciprocal benefit to the community and fulfils the values of social enterprise. Various reports have affirmed the benefits of social entrepreneurship approach in sustainable entrepreneurship. For example, Militaru and Ionescu (2007) showed that a social approach to entrepreneurship have trippled the alliance between corporations and society in Lebanon and Romania leading to mutual reciprocity between the two entities. Porter's shared value model is an excellent example of social 
entrepreneurship in sustainable business. It is an invaluable model that puts social entrepreneurship in context.

The foregoing arguments clearly explored the impact of social entrepreneurship on the trajectory of entrepreneurship. It will be recalled here again that social entrepreneurship alters the trajectory of entrepreneurship in three levels. Firstly, social entrepreneruship can alter the motivation of entrepreneurship and the vision and mission of a business firm. Social entrepreneurship dictates that an entrepreneur has to abide to minimum standards of morality. Breaching the minimal standard would ensue socio-political repercussions that in turn alter the trajectory of the entrepreneurial motivation from purely commercial consideration to a moral blend. Secondly, social entrepreneurship has significant impacts on innovation. Social entrepreneurship supervises the "permissionless innovation" and insert moral values and considerations in innovation. Entrepreneurs are prohibited to innovate products and services that destroy and diminishes moral values but are conversely required to inject moral values in their innovations. Lastly, social entrepreneurship plays a vital role on how entrepreneurs should defend and sustain its entrepreneurship. Instead of defending them from a conventional strategic point, social entrepreneurship requires entrepreneurs to consider generating long term alliances with its value chain to generate a long term synergistic impact. Starbucks and Nestle are great examples in showcasing the values of social entrepreneurship in generating such long term impact in sustainable business.

\section{The Future of Social Enterprise as a Foundation of Motivation, Innovation in Entrepreneurship}

Social enterpreneurship is a justaposed concept. Business entrepreneurs have never liked this concept. It has never fitted well in conventional entrepreneurship. Enterprises are designed to make profit and not to fulfil social welfare. The powerful shareholder model still dictates the mainstream perception that entrepreneurs exist to maximise self interests and the interests of its shareholders. Of course, business and social welfare have always been a separate discourse. Friedman (1970) argued that corporations have no moral duty whatsoever to the society. According to him, the term social responsibility lacks rigor because business corporations are artificial persons and thus, they do not share moral responsibilities. The only responsibility a firm is to "maximise the interests of the shareholders'. But it does not mean that firms have no duties at all. Firms have an inherent fiduciary duty to increase the shareholders' profits. An internally directed moral duty.

Despite significant evolution, social entrepreneurship have not changed much and is probably a superficial concept. This fundamentally raised the question on its true value in spawning entrepreneurial transformations in organisation (Higgins, 2010). Most literatures on CSR and social entrepreneurship were superficial and presented merely lip service, nothing more than window dressing. Social entrepreneurship and CSR movements reflected a management genre, one that closely resembled a stakeholder and crisis management. If this is so, then management based CSR integration models lack ethical core. It superficially led firms to pursue ethical positioning, an overlapping concept between virtue ethics and strategy management (Rakesh, et al, 2013). This prompted business firms to apply CSR in areas of practice deemed profitable for them, neglecting the rights and interests of marginalised groups that are often considered to be unessential stakeholders of the firm. Social entrepreneurship exercised in the form of CSR delimits the contributions a corporation can undertake and only those that present competitive opportunities for the firm.

There are other concerns. Social enterprise has instigated increasing encroachment of government jurisdiction in freedom to innovate. This is a worrying trend as this inteference is deemed dangerous because institutionalising responsible innovation would mean increasing regulations and increasing supervisory role of the government. This opens up wider context of possible corruption, abuse and delimits leap bound innovations. It deliberately kills entrepreneurship. Already, business firms and entrepreneurship are already increasingly bound by rigid rules of corporate governance.

There is no easy solution for this and it is envisaged that the dilemma between the need for social entrepreneurship versus the need to stay ahead of competition will continue. It is argued that Porter's CSR model lacks a pure ethical approach to social enterpreneurship whilst a regulatory approach to innovation fuels the confrontation between capitalism and governance. What is clear however is that social enterpreneurship do have significant values in remaking entrepreneurship in modern society. Cases such as Shell and the recent Volkwagen Diesel Dupe are excellent examples that entrepreneurs that breach the minimalist value of social enterprise will face severe repercussions that will change the trajectory of entrepreneurial motivation, innovation and sustainability.

\section{References}

Albert, C. (1968). Is Business Bluffing Ethical. Harvard Business Review. Retrieved December 4, 2017, from https://hbr.org/1968/01/is-business-bluffing-ethical 
Ana, M. P., \& Mclean, M. (2015). Social Enterprise, A Critical Review of Concepts. Journal of World Business 41, 56-65. https://doi.org/10.1016/j.jwb.2005.10.007

Dee, J. G. (1998). The Meaning of Social Entrepreneurship, Stamford University. Draft Report for the Kauffman Center for Entrepreneurial Leadership.

Ewans, S. (25th September, 2017). iPhone X Kills iPhone 8 And Exposes Tim Cook's Risky Gamble. Retrieved October 17, 2017, from https://www.forbes.com/sites/ewanspence/2017/09/25/apple-iphonex-iphone8-risk-gamble-danger-sales/\#69 $2 \mathrm{fb} 8547531$

Frese, M., \& de Kruif, M. (2010). Psychological success factors of entrepreneurship in Africa, a selective literature review. In Frese, M. (Ed.), Success and Failure of Microbusiness Owners in Africa: A Psychological Approach. London: Quorum Books as cited in Rosa, P. J., Kodithuwakku, S., \& Balunywa, W. (2012). "Entrepreneurial Motivation in Developing Countries: What Does Necessity" and "Opportunity" Entrepreneurship Really Mean? Frontiers of Entrepreneurship Research, 26(20), Art 4.

Gilbert, J. T. (1994). Choosing an innovation strategy: Theory and practise. Business Horizons, 37(6), 16. https://doi.org/10.1016/S0007-6813(05)80240-X

Goodell. J, (1994, June). Steve Jobs in 1994: The Rolling Stone Interview. Rolling Stone, 683, 73-79.

Higgins, C. (2010). Is a Responsive Business also a Responsible Business? Journal of Business Systems, Governance and Ethics, 5(3). https://doi.org/10.15209/jbsge.v5i3.186

Hisrich, R. D. (1985). The woman entrepreneur in the United States and Puerto Rico: a comparative study. Leadership and Organizational Development Journal, 5, 3-8. https://doi.org/10.1108/eb053558

Jeffrey, A. T. (1994). New Venture Creation (4th ed.). Irwin Press.

John, S. (2011). Measuring Personality and Entrepreneurship. Business Horizons, 2(16).

Kauffman \& Dant. (2008). Innovating Responsibly. Journal of Business Ethics, 3, 56-76.

Lantos, G. P. (2001). The Boundaries of Strategic Corporate Social Responsibility. Journal of Social Science, $17(2), 45-53$.

Locke, E. A. (2000). Motivation, cognition and action: an analysis of studies of task goals and knowledge. Applied Psychology: An International Review, 49, 408-429. https://doi.org/10.1111/1464-0597.00023

McClelland, D. C., Clark, R. A., Roby, T. B., \& Atkinson, J. W. (1958). The effect of the need for achievement on thematic apperception as cited in Collins, C. J., Hanges, P. J., \& Locke, E. A. (2004). The relationship of achievement motivation to entrepreneurial behavior: A meta-analysis. Human Performance, 17(1), 95-117.

Militaru, G., \& Ionescu, S. (2007). Integrating Business and Society: The Link between CSR and Competitive Advantage. U.P.B. Sci. Bull., Series D, 69(2).

Mort, G. S., Weerawardena, J., \& Carnegie, K. (2003). Social entrepreneurship: Towards conceptualization. International Journal of Non-Profit and Voluntary Sector Marketing, 8(1), 76-89. https://doi.org/10.1002/nvsm.202

Peter, J., Kodithuwakku, S., \& Balunywa, W. (2012). Entrepreneurial Motivation in Developing Countries: What Does "Necessity" and "Opportunity" Entrepreneurship Really Mean? Frontiers of Entrepreneurship Research, 26(20).

Peter, J. R., Malcolm, S., \& Jennifer, L. (2012). What is motivating our entrepreneurs? Journal of Business Ethics, 5, 98-110.

Porter, M. E., \& Kramer, M. R. (2009). Strategy and Society: The Link Between Competitive Advantage and Corporate Social Responsibility. Harvard Business Review, 84(2), 78-92.

Rakesh, S., Tan, S. T., \& Yap, T. F. (2013). A Critical Review on Porter's Integrated Approach towards Corporate Social Responsibility. IJBMT, 3(8).

Schumpeter, J. A. (1934). The theory of economic development: An inquiry into profits, capital, credit, interest, and the business cycle. Cambridge, MA: Harvard University Press.

Shane, S., Locke, E. A., \& Collins, C. J. (2012), Entrepreneurial motivation, electronic version. Retrieved December 4, 2017 from http://digitalcommons.ilr.cornell.edu/articles/830

Shane, S., \&Venkataraman, S. (2000). The promise of entrepreneurship as a field of research. Academy of 
Management Review, 25, 217-226. https://doi.org/10.5465/amr.2000.2791611

Shaw, W. H., Barry, V., Issa, T., \& Catley, B. (2013). Moral Issues in Business (2nd ed.). Australia: Cengage Learning.

Stilgoe, J., Richard, O., \& Phil, M. (2013). Developing a Framework for Responsible nnovation. Research Policy, 42(9), 1568-1580. https://doi.org/10.1016/j.respol.2013.05.008

Tan, S. T. (2012). Human Rights: Do Businesses Have Roles and Obligations as Corporate Citizens? The Law Review, 2, 46-54.

Tellegen, N. (2011). Rural Enterprises in Malawi: Necessity or Opportunity? Ashgate: African Studies Centre Leiden.

Thierer, A. D. (2014). Permissionless Innovation: The Continuing Case for Comprehensive Technological Freedom. Arlington, VA: Mercatus Center, George Mason University.

Walter, D. V., \& David, H. G. (2015). Responsible innovation: A primer for policymakers. Center for Technology Innovations at Brookings.

\section{Copyrights}

Copyright for this article is retained by the author(s), with first publication rights granted to the journal.

This is an open-access article distributed under the terms and conditions of the Creative Commons Attribution license (http://creativecommons.org/licenses/by/4.0/). 